\title{
Beyond Local Memories: Exhumations of Francoism's Victims as Counter-discourse during the Spanish Transition to Democracy
}

\author{
Zoé de Kerangat
}

The Spanish Civil War started in July 1936, when military generals conducted a coup against the Second Republic. As they failed to conquer the entire territory, the coup unfolded into the Civil War. At the start of the war, repression against civilians was dreadful. In the areas that remained loyal to the Republic, uncontrolled groups of people killed members of the clergy and landowners who were seen as exploiting the labour force. In the areas that had turned against the Republic, instructions were given to the population by rebel generals to violently repress anyone who was suspected of supporting the Republic or being left-wing. The objective was to erase the roots of the left completely. The number of civilian victims is still debated, but it is estimated that almost 60,000 were killed on the rebel side, and more than 100,000 on the side that was loyal with the Republic. ${ }^{1}$ A great proportion of those crimes took place in the first months of the war. When the Second Republic recovered control after an initial period of confusion, illegal repression against the conservatives virtually stopped and the executions became part of processes of justice. The rebels' repression continued throughout the war and the first years of dictatorship, although to a lesser extent than in the first months of the Civil War. General Francisco Franco soon became the leader of the rebel side. In April 1939, when the war ended with the Francoist victory, he became the head of the dictatorship. Most of the dead on the Francoist side were exhumed and honored directly after the end of the war, as part of the construction of the Francoist rhetoric of martyrdom. ${ }^{2}$ However, the thousands of victims of Francoism were left buried in unmarked mass graves across the Spanish territory. These mass

1 Julián Casanova, España Partida En Dos: Breve Historia de La Guerra Civil Española (Barcelona: Crítica, 2013).

2 Zira Box, España Año Cero. La Construcción Simbólica Del Franquismo (Madrid: Alianza, 2010). 
graves were part of what has been called the 'topography of terror,, ${ }^{3}$ acting as an instigator of fear in society, by reminding people about the consequences of opposing the Francoist regime.

Dictator Franco died while he was still in power in 1975. Soon after his death, the period of transition to democracy started. It was a very intense period in terms of institutional and political negotiations, but also a period of conflict, fear and uncertainty. As democracy developed, a tacit agreement among politicians was reached in order for the transition to be smooth. An amnesty law was passed in 1977, freeing the political prisoners jailed by the Francoist authorities, but also preventing the Francoist perpetrators from being prosecuted. Under the so-called 'Pact of Silence', there would be no mention of the victims of Francoist repression. Paloma Aguilar defines the 'Pact of Silence' as a 'tacit agreement during the transition to silence the crimes of the Civil War and Francoist repression'. ${ }^{4}$ In this sense, silence was intentional. However, the 'Pact of Silence' was in fact limited to the institutional sphere and not a real social agreement. What is more, according to Aguilar, ${ }^{5}$ the memory of the Civil War was indeed highly present in the sense that most Spanish people thought a new armed conflict was possible at the time. Thus, the argument not to bring the history of the repression into debate was in fact triggered by the very memory of the Civil War. The Spanish society wanted to avoid a new conflict at all costs, and - according to the discourse of consensus - to maintain peace, it was necessary to avoid looking back. The new dominant discourse of national reconciliation was hence based on intentional 'oblivion'. What was not possible, under the 'Pact of Silence', was to use the recent history of violence and demands of justice for the repressed as political leverage in the new Spanish democracy. Political actors such as the Socialists and Communists, illegal and repressed during the dictatorship, were allowed to come back from exile or clandestinity, under the condition that they would abide by this unwritten rule. Nevertheless, the limit of what was allowed was not clearly stated. As the nature of the so-called pact was tacit it was rather a try - and - see process. ${ }^{6} \mathrm{As}$

3 Francisco Ferrándiz, El Pasado Bajo Tierra: Exhumaciones Contemporáneas de La Guerra Civil (Barcelona: Anthropos, 2014), 192.

4 Paloma Aguilar, "Justice, Politics and Memory in the Spanish Transition," in The Politics of Memory. Transitional Justice in Democratizing Societies, ed. Alexandra Barahona de Brito, Carmen González Enríquez, and Paloma Aguilar (Oxford: Oxford University Press, 2008), 92-118.

5 Paloma Aguilar, Políticas de La Memoria Y Memorias de La Política: El Caso Español En Perspectiva Comparada (Madrid: Alianza, 2008), 250-303.

6 Lidia Mateo Leivas and the author are currently publishing an article entitled "The limits of remembrance during the Spanish Transition: Questioning the "Pact of Oblivion" through the 
we will see in the following, in some places the recovery of the memory of the victims of Francoism went further than in others - because of the restrictions some people were faced with or the audacity some showed - and it is necessary to make the difference between what happened at State level and the local actions and initiatives across Spain.

As a result of the 'Pact of Silence', the institutional initiatives regarding reparations to the victims of past violence remained limited to the pension law of 1979. The law gave the widow/ers and children of people who died during the Civil War the right to receive a pension. This meant that the dead on the Republican side were now also taken into consideration. In order to claim the pension, the widows or relatives had to show proof of the death of their relative under the conditions contemplated by the law. ${ }^{7}$ Exhuming the remains, in some cases, was a way to produce or induce the pieces of evidence and testimonies necessary to get a death certificate, although indirectly, as no forensic identification or certification of death was issued at the time. The pension law was not the direct trigger for the exhumations of the late 70 and early $80 \mathrm{os}-$ many in fact took place before - but as the only institutional policy to deal with reparations, it is definitely a significant element to take into account.

This chapter studies the wave of mass grave openings in the late 1970s and early 1980s. The interest for this topic emerges from the realization that many exhumations in fact took place before the 'boom', starting in 2000. ${ }^{8}$ Indeed, when some of the graves were opened in the 21st century, parts of the bodies were missing, meaning that the grave had been opened before and that someone had taken the remains. On the other hand, the higher media impact of the 21st-century exhumations meant that an increasing number of people came forward to tell their story of the Civil War and of the repression, including people who had taken the initiative to exhume some of the graves decades ago. It is time to look into these exhumations as it is important to acknowledge them as one of the phases of mass grave openings since the Civil War.

analysis of a censored film and a mass grave exhumation" about the containment of memory during the Spanish Transition, in which we analyze two examples of what was allowed in terms of memory initiatives at the time.

7 "Real Decreto 2635/1979, de 16 de Noviembre, Para La Aplicación Y Cumplimiento de La Ley 5/1979, de 18 de Septiembre, Sobre Concesión de Derechos a Los Familiares de Los Españoles Fallecidos Como Consecuencia O Con Ocasión de La Pasada Guerra Civil," 16 November 1979, Agencia Estatal Boletín del Estado, https://www.boe.es/diario_boe/txt. php?id=BOE-A-1979-27535.

8 Emilio Silva, Las Fosas de Franco (Madrid: Temas de Hoy, 2005).; Ferrándiz, El Pasado Bajo Tierra: Exhumaciones Contemporáneas de La Guerra Civil. 
The research carried out in Spain is based on different kinds of material. The main sources of investigation are interviews with the people who were involved in the exhumations of the bodies from mass graves, and/or local activists who have researched the repression in their village or area and know how the victims were exhumed and later honoured. These people often have pictures, or even audio and video recordings of the events. In some cases, a few official documents are available in the local archives (such as reports of the plenary sessions at the town hall where the re-burial is discussed). We can also find informal documents people have saved, with information about the costs of the exhumations and re-burials, for example, or reports of their informal meetings. In a few cases, there are short press reports published in the local media about the ceremonies after the exhumations. Last but not least, the secondary sources on the Civil War and repression in specific areas are very helpful to gather more information, corroborate or contrast the data.

In the case of Arnedo presented in this chapter, the main source of information is an interview with Carlos Solana, a local activist who participated in activities for the recovery of memory and interviewed the people of Arnedo about the stories of their families. He also showed pictures of the ceremony of re-burial which he attended and had an audio-recording of the mass that was celebrated. Also, the book Aquí nunca pasó nada by Jesús Vicente Aguirre contains helpful information about what happened in Arnedo.

The methods used are the hermeneutical analysis of the interviews combined with the interpretation of the information given by the pictures, audio and video recordings, official documents and secondary sources. It has to be said that, as the repression and most of the exhumations of remains from mass graves we are dealing with were informal, the information is sometimes confusing or contradictory. However, the interest of this piece of research lies in analysing the meaning that was given to those initiatives of recovery of memory in a context of fear and silence, right after the end of Franco's dictatorship. In this sense, and given the type of sources analyzed in this piece of research, it can be defined as 'history from below' in Jim Sharpe's terms, ${ }^{9}$ in which the point of start is the local people and their cases of exhumations. The case-studies are then framed both in their broader political and historical context, and in the conceptual and theoretical framework developed through the analysis.

In the following, the exhumations of the Spanish transition will first be presented as part of the construction of local counter-discourses to the 'Pact of Silence'. In the second part, the framework will be expanded beyond Spain, to

9 Jim Sharpe, "Historia Desde Abajo," in Formas de Hacer Historia, ed. Peter Burke, Segunda edición (Madrid: Alianza, 2003), 39-58. 
relate the Spanish exhumations to the ones of the Greek transition in particular, showing that the local counter-discourses in fact go beyond the local sphere of memory practices and discourses. Looking at the kind of counter-discourse they produced, this chapter aims at opening up the view on grass-root memory practices such as the exhumations in Spain to new interpretations of the Spanish transition, also in connection to other cases such as the Greek one.

\section{Exhuming the Past: A Negotiated Counter-discourse to the 'Pact of Silence'}

Despite the difficult political circumstances of the transition, hundreds of people, mainly families of the victims, decided that now that Franco was dead and the dictatorship over, they could finally unearth the remains of their relatives in order to give them a proper burial and to have them rest in a dignified grave.

These processes started and remained informal, with no official policy supporting them. In fact, there was no specific policy whatsoever on what to do with the thousands of mass graves around Spain. As a result of the mostly informal nature of these processes, they did not leave much written documentation behind. When requested by the promoters of the exhumations, permissions to excavate were granted by the local authorities, but not without problems. There were threats, and concessions had to be made. To give an example, in Casas de Don Pedro in 1978, the procession for the re-burial of the remains was allowed by the Civil Governor under the condition that there would be no political slogans. ${ }^{10}$

Indeed, the conditions in which these groups of people carried out the exhumations were far from ideal. Although the dictatorship was over, fear among the population was still very present. Apart from the difficulties to find the graves and the occasional resentment of the local administration to allow the exhumation, the people involved were also despized by their fellow villagers. In some villages, the attendants were insulted during the procession. ${ }^{11}$ Moreover, they could not count on scientific support during the exhumations. There were, most probably, many mistakes made and no forensic identification. In most cases, the remains were reburied in collective vaults. What bound these groups together and formed a community was the desire to give dignity back to the victims through the re-burial of their remains.

10 Personal communication with Felisa Casatejada, Casas de Don Pedro, May 2015.

11 Josefina Campos Orduña, Los Fusilados de Peralta, La Vuelta a Casa (1936-1978). Operación Retorno (Pamplona/Iruña: Pamiela, 2008), 334. 
The transition exhumations show aspects of both resistance and compliance, as the case of Arnedo - a village in La Rioja, in the north of Spain - exemplifies. In Arnedo, 46 people were murdered during the repression of the Civil War against the left. ${ }^{12}$ They were taken in different sacas (the term used when people were taken out of jail or their homes to be killed elsewhere, most often outside the village), and murdered in different places in La Rioja or the neighboring region of Navarra, where they were buried in unmarked mass graves and left there for the entire dictatorship.

When Franco died, a movement started in Navarra and La Rioja to exhume the remains of the victims of Francoist repression. ${ }^{13}$ The phenomenon spread on both sides of the Ebro River, with the help of a group of priests who actively supported and participated in these initiatives. In Arnedo, too, families decided to go and unearth the victims' remains. They first had their meetings almost clandestinely, in the backroom of a bar. ${ }^{14}$ They were trying not to attract attention. Most of the times, they knew the place where their relatives had been buried. The location and the history of the mass graves were usually known among the population, although not talked about during the dictatorship and sometimes not even today, because of fear.

The families of Arnedo started opening the graves in 1978, with the help of diggers. They even removed the last bits of earth with spoons in order not to damage the remains. ${ }^{15}$ They exhumed bodies in various villages of La Rioja and Navarra - Ausejo, Lerín, Arnedillo or Calahorra - and they put the remains together in one coffin each time. Awaiting the funeral, the coffins with the remains were stored in the premises of the Red Cross. The mayor who was elected in the first democratic local elections in 1979 in Arnedo was a known Francoist. He was now part of Alianza Popular, the party founded by former politicians of the Francoist system after the dictatorship. However, when asked for permission to rebury the remains of the victims of Francoist repression in the cemetery of Arnedo, he was pleased with the idea. ${ }^{16} \mathrm{He}$ made things easy, and the piece of land of the cemetery where the pantheon was built was unanimously ceded to the families, at no cost and in perpetuity. In May 1980, the re-burial took place with a church funeral followed by a silent procession with the coffins to the cemetery.

12 Jesús Vicente Aguirre González, Aquí Nunca Pasó Nada. La Rioja 1936, 5 a edición (Logroño: Editorial Ochoa, 2008), 288.

13 These two were not the only regions where exhumations took place in the late 1970s, but there the grave openings had a kind of a domino effect, the word spreading from village to village that the relatives of the victims were bringing their loved ones 'back home'.

14 Personal communication with Carlos Solana, Arnedo, December 2014.

15 Ibid.

16 Ibid. 
On the one hand, despite the threats and people's fear, political symbols were present. In Arnedo, huge Republican flags were used in the streets during the procession and funeral of the victims after the exhumation (see Figure 5.1). They were even displayed at the church where the funeral took place. ${ }^{17}$ This happened when the Spanish Communist party itself had given up on displaying Republican flags during their events (and instead had adopted the official Spanish flag at the time) since $1977,^{18}$ as the party was looking for inclusion into the political system and was thus complying with the discourse of consensus and apparent silence. It seems to have been the first time those flags came back to the public space of Arnedo in such a visible way since the end of the Second Republic. ${ }^{19}$ Even though the political symbols and discourse may not have been as visible in some other cases, the very act of exhumation is

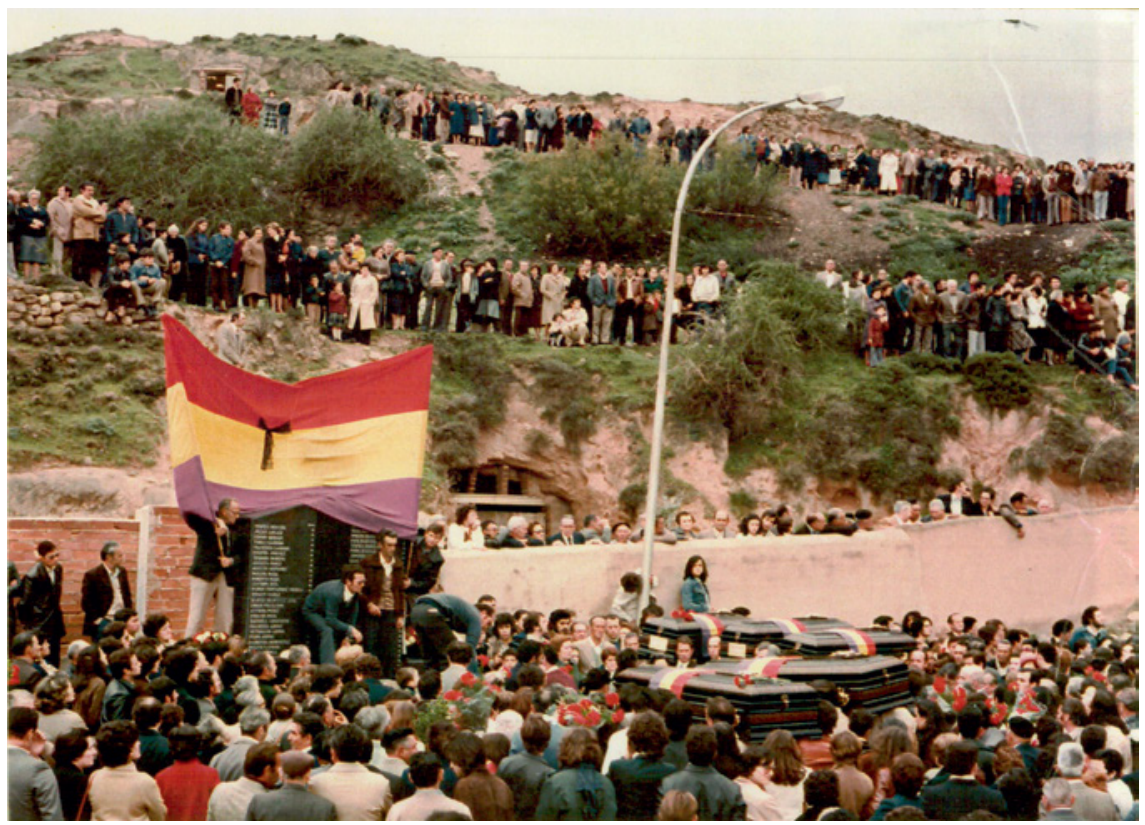

Figure 5.1 Arnedo (La Rioja, Spain), 4 May 1980

PICTURE CEDED BY CARLOS SOLANA

17 Ibid

18 Joaquín Prieto, "La Bandera Nacional Ondeará En Los Actos Del Partido Comunista de España," El País, de abril de 1977, http://elpais.com/diario/1977/04/16/ espana/229989610_850215.html.

19 Personal communication with Carlos Solana, Arnedo, December 2014. 
political, because dead bodies turn into political symbols ${ }^{20}$ when they bring a violent past into the present and as they are moved from one place to another. In short, the exhumations and the presence of these symbols were dissident in the context of the transition to democracy.

On the other hand, the processes of exhumation and re-burial were also impregnated by religion - Catholic in most Spanish cases - although the Church had taken an important part in the Francoist repression of the 1930s. Many local priests were actively involved in the exhumations. They helped searching for information and organizing funerals which were often requested by the families. In Arnedo in 1980, the local parish priest - who was apparently obliged by the Bishop ${ }^{21}$ - attended the procession and funeral (see Figure 5.2). During the funeral, another clergyman, who came from Navarra and was one of the priests who had supported all the exhumations, added something quite exceptional to the church service, given the context: he asked for forgiveness

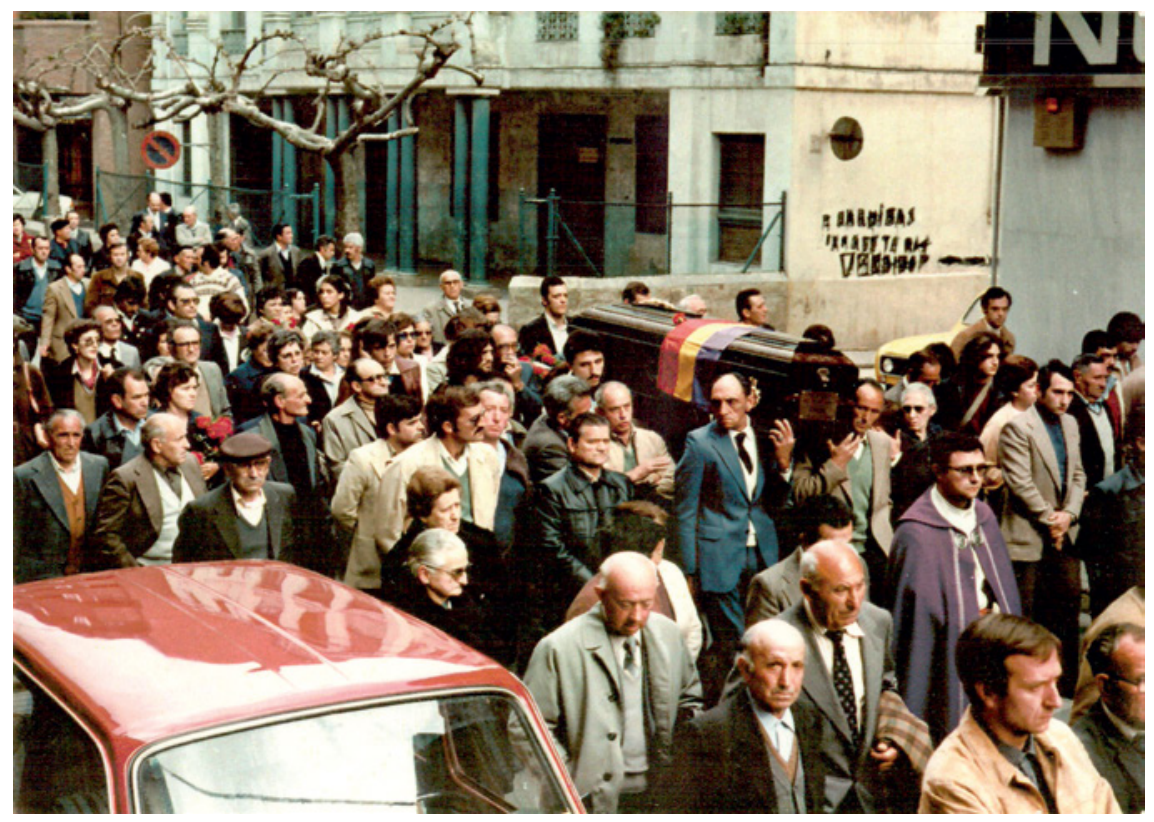

Figure 5.2 Arnedo (La Rioja, Spain), 4 May 1980

PICTURE CEDED BY CARLOS SOLANA

\footnotetext{
$20 \quad$ Katherine Verdery, The Political Lives of Dead Bodies (New York: Columbia University Press, 1999), 3.

21 Personal communication with Carlos Solana, Arnedo, December, 2014.
} 
in the name of the Church for its involvement in the repression. ${ }^{22}$ It has to be mentioned as well, that the mayor who authorized the remains to be reburied in the village cemetery thought it was a good idea to do it 'como Dios manda' [As God ordains]. ${ }^{23}$

Religious rituals and symbols were also very present. Indeed, in many of the funerals organized after the exhumations, Christian crosses were displayed and women followed the custom of wearing black clothes as a sign of mourning. The religious aspect was also part of the families' public recognition of the death of their relative as such, completing the traditional process of mourning they had been denied during the dictatorship. Basically, it was a claim for the right to comply with cultural customs: 'their' victims had a right to a funeral and decent grave. But in doing so, and by making concessions, they were also complying with the established order. That is, they were simultaneously disrupting and complying with the transitional order.

This double sense given to the exhumations gave rise to situations that may seem contradictory, such as priests taking part in a procession where Republican flags were displayed. Nevertheless, they reveal that these practices were in fact the local results of a negotiation between resistance and (self-) censorship. Although this might reflect a contradiction, we can also consider it a strategical move in order to make sure that the exhumation and reburial would actually be approved. Because the discourse of silence was enforced upon them, ${ }^{24}$ the groups of people who wanted to exhume the bodies had to be discreet to reach their goal. They adapted their practices and discourses to the circumstances, that is, the limits given by the 'Pact of Silence' within which they (thought they) could act.

Despite the concessions, these initiatives were transgressive of the established order, because they represented a crack in the discourse of silence and the consensus promoted during the transition. The transgression might not have been strong enough to worry the elites, but it was nevertheless an inflection on the dominant discourse in the public space, at a local level. They avoided a direct clash, while trying to remain as faithful as they could to the memory of the victims in their tribute. These exhumations were a form a subthe resistance to the 'Pact of Silence', as part of the 'infrapolitics of subordinate groups' defined by James Scott as 'low-profile forms of resistance that dare not

$22 \quad$ Funeral a Los Fusilados de Arnedo (Arnedo, 1980).

23 Aguirre González, Aquí Nunca Pasó Nada. La Rioja 1936, 278.

24 Andrea Davis, "Enforcing the Transition: The Demobilization of Collective Memory in Spain, 1979-1982," Bulletin of Hispanic Studies 92, no. 6 (2015): 667-689, doi:10.3828/ bhs.2015.40. 
speak in their own name..25 In this sense, mourning the dead - mourning those precise dead in that precise context - was part of a counter-discourse to the 'Pact of Silence'.

The counter-discourses were the result of the reception of the 'Pact of Silence' and of the reaction to this dominant discourse. According to Wulf Kansteiner, cultural memory is the result of three interacting factors: intellectual and cultural tradition that frames all our representations of the past, memory makers who selectively adopt and manipulate these traditions and memory consumers who use, ignore, or transform such artifacts according to their own interest. ${ }^{26}$ In this setting, the three factors interact. Memory consumers, when transforming the representations, also become memory makers as they mediate new representations of the past. In this sense, they receive memory discourses and produce new ones.

The discourse of the 'Pact of Silence' was received and consumed by many families of the victims of Francoism, who in turn became memory makers by adapting this dominant discourse to their own situation. Exhuming the remains from the mass graves contributed to the creation of a different representation of the victims than that imposed by the order of the transition. The exhumation of the bodies and their re-burial in a decent grave play a part - by turning the body into symbol - in the revaluation of the status of the victims. This diverging representation emerging from the exhumations produced a memory discourse promoting the dignification of the memory of Francoism's victims to counter the official silence about them. Without being explicit, the families demonstrated that paying a pacific tribute to the dead through the grave openings did not mean looking for another conflict. They showed it was possible - and actually fair - to dignify the victims in the context of the transition. Thus the discourse promoted was one of symbolic justice in the memory of the Civil War and the deathly repression during the dictatorship. In turn, the emergence of counter-discourses affected the dominant one, in the sense that it forced the elite to find ways of discreetly making sure those local counterdiscourses would not spread by implementing new mechanisms of containment and silencing. ${ }^{27}$

25 James Scott, Domination and the Arts of Resistance: Hidden Transcripts (New Haven and London: Yale University Press, 1990), 19.

26 Wulf Kansteiner, "Finding Meaning in Memory: A Methodological Critique of Collective Memory Studies," History and Theory 41 (2002): 180.

27 See the forthcoming article by Lidia Mateo Leivas and the author: "The limits of remembrance during the Spanish Transition: Questioning the "Pact of Oblivion" through the analysis of a censored film and a mass grave exhumation." 
Despite their emergence, the exhumations of the 7os and 8os received limited media attention. ${ }^{28}$ As a result of the limited media impact of the exhumations, their silencing and their relative discretion, the counter-discourses produced by these acts remained invisible to the national sphere and stayed confined to local areas at a grass-root level. They did not enter what Foucault calls the 'regime of truth': the types of discourse which society 'accepts and makes function as true. ${ }^{29}$ In this struggle of memory discourses, the different representations of the past were made visible to a very uneven degree. Although the counter-discourses did not get to be mediated in the main channels of communication and institutions, it is important to take them into account, as they offer a different point of view on the history of the transition. The transition was not indeed all about leaving the past behind. The study of grass-root actors demonstrates that the 'oblivion' of the transition is in fact one of many assumptions about that period. There was opposition to silence and it is necessary to look for it, away from the dominant discourse.

\section{Exhumations across Time and Space}

This type of local counter-discourse against silence actually fits into a larger historical and transnational discourse than that of the Spanish transition, and the grave openings should not be considered isolated events. Indeed, exhuming the victims of political violence was not anything new. The post-World War $\mathrm{I}^{30}$ and World War $\mathrm{II}^{31}$ periods saw the unearthing and moving of victims' remains across different European countries. As far as the exhumations of bodies from the Spanish Civil War mass graves are concerned, the ones carried out in the 1970s and 1980s were not the first either. The genealogy of exhumations

28 One of the exceptions in the national media is the magazine Interviú, in which thirteen reports on the mass graves were published between 1976 and 1984, although Interviú was not part of the mainstream media. For more on this topic see: Paloma Aguilar and Francisco Ferrándiz, "Memory, Media and Spectacle: Interviú's Portrayal of Civil War Exhumations in the Early Years of Spanish Democracy," Journal of Spanish Cultural Studies 17, no. 1 (2016): 1-25, doi:10.1080/14636204.2015.1135599.

29 Michel Foucault, "Truth and Power (interview with Alessandro Fontana and Pasquale Pasquino)," in The Foucault Reader, ed. Paul Rabinow, Pantheon (New York, 1984), 72-73.

$30 \quad$ Jay Winter, Sites of Memory, Sites of Mourning. The Great War in European Cultural History (Cambridge: Cambridge University Press, 1995).

31 Jean-Marc Dreyfus, "Une Renationalisation Des Corps? La Mission Française de Recherches Des Cadavres de Déportés En Allemagne, 1946-1958," in Cadavres Impensables, Cadavres Impensés, ed. Elisabeth Anstett (Paris: Pétra, 2012), 67-78. 
can be divided into the following phases: the postwar (mainly Francoist, but also Republican clandestine exhumations), the moving of thousands of bodies to Franco's future mausoleum - the Valle de los Caídos - during the dictatorship, the transition exhumations and finally the latest wave of exhumations that started in 2000. ${ }^{32}$ Each phase had its own form of necropolitics. ${ }^{33}$ If we focus on the 1970s and 1980s, Argentina was also the scene for exhumations of the victims of past violence. At the end of the Junta dictatorship, in 1984, the search for the desaparecidos - the people who had been abducted, detained and killed illegally by the military - became official. The Madres and Abuelas de la Plaza de Mayo had been looking for their children and grandchildren for years, but now that the dictatorship was over, the search was in the hands of justice. The first exhumations of bodies were conducted by the authorities, but there were many mistakes made and evidence was unintentionally destroyed. ${ }^{34}$ Soon, independent forensic anthropologists ${ }^{35}$ took over and have worked on the search for disappeared people in Argentina and across the world ever since.

All in all, exhuming the victims of violence for the purpose of dignification be it returning them to their families, as part of a State policy of honouring the 'fallen', or a justice procedure - is embedded within the so-called Western traditions. Hence, the grave openings we are dealing with in this chapter do not emerge out of nowhere.

Most interestingly, similar exhumations to that of the Spanish transition took place in Greece in the same period. ${ }^{36}$ The Greek Civil War (1946-1949) opposing the left-wing forces of the Democratic Army of Greece and the armed section of the Greek Communist party on the one hand, and the right-wing Greek government on the other, also left many unmarked graves as a result of the atrocities committed on both sides. When Greece's dictatorship was over in 1974, the policies of national reconciliation were not comprehensive and did not contemplate exhumations of the bodies in the mass graves. Katerina Stefatos and Iosif Kovras even speak of a 'subtle agreement [...] reached to silence

32 Ferrándiz, El Pasado Bajo Tierra: Exhumaciones Contemporáneas de La Guerra Civil, 148.

33 Achille Mbembe, "Necropolitics," Public Culture 15, no. 1 (2003): 11-40.

34 Mauricio Cohen Salama, Tumbas Anónimas. Informe Sobre La Identificación de Restos de Víctimas de La Represión Ilegal (Buenos Aires: Catálogos editora, 1992); Christopher Joyce and Eric Stover, Witnesses from the Grave. From Mengele to Argentina's "Disappeared" - The Stories Bones Tell (London: Grafton, 1993).

35 The Argentine Forensic Anthropology Team (EAAF in Spanish)

36 I would like to thank Iosif Kovras and Katerina Stefatos for discussing this with me and for shedding light upon the Greek case. For more information, please refer to their publication listed in the bibliography. 
certain inconvenient aspects of the violent past'. ${ }^{37}$ Indeed, the institutional memory politics of the Greek democratic consolidation share characteristics with those of the Spanish transition. It is also worth noting that both postdictatorial processes coincide in time. Another point of convergence is the politics regarding reparations to former leftist veterans of the civil war. While the Spanish pension law was passed in 1979, similar measures were adopted in Greece in 1985 with a law restoring pension rights to public servants formerly dismissed for political reasons and providing for pensions to disabled or partly disabled veterans of the resistance. ${ }^{38}$

Amid partial silence on the past from the side of the government, the Greek island of Lesvos was the scene of the very few exhumations of the bodies of former resistance and Communist fighters that had died during the civil war. Stefatos and Kovras distinguish between three periods of exhumations: secrecy in the 1950 and 1960 , the most visible wave in the 1980 s and a renewed interest for exhumations in 2009. ${ }^{39}$ Again, this sequence is reminiscent of the Spanish one. In the 1980s, the bodies from Civil War mass graves were exhumed in the Agiasos pine forest (1982), in Mytilene (1982), Lambous Mylous (1983), Aghia Paraskevi (1983) and there was an unsuccessful attempt in Eressos (1985). Similarities can be found in the practice of exhuming and dignifying the victims. In both cases, scenes of people gathering around the open coffins or the boxes containing the remains to take pictures after the exhumations can be observed. Another similarity is that there is little information about them, except for oral testimonies and material traces. Moreover, the mix of religion and politics can be found in the features of Lesvos identity, with a blend of Orthodox faith with leftist-communist convictions. ${ }^{40}$ This is reflected in the re-burial ceremonies as well: there were religious ceremonies officiated by priests and women wearing black and crying as part of the mourning process, while local Communist party members were present. The exhumations in Lesvos were also described as local and informal ones: '[...] with no official endorsement by political parties or the government. They were initiated by the local communities. ${ }^{41}$ We have to bear in mind, nevertheless, that Lesvos was an outlier case

37 Katerina Stefatos and Iosif Kovras, "Buried Silences of the Greek Civil War," in Down to Earth: Exhumations in the Contemporary World, ed. Francisco Ferrándiz and Antonius Robben (Philadelphia: University of Pennsylvania Press, 2015), 165. David Close, "The Road to Reconciliation? The Greek Civil War and the Politics of Memory in the 1980s," in The Greek Civil War. Essays on a Conflict of Exceptionalism and Silences, ed. Philip Carabott and Thanasis D. Sfikas (Aldershot: Ashgate, 2004), 266. Stefatos and Kovras, "Buried Silences of the Greek Civil War," 167-168.

$40 \quad$ Ibid., 173 .

41 Ibid. 
and that most of the mass graves of the Greek Civil War remain unopened. It does demonstrate, however, that in Greece, too, we need to look closer at the local level to find disruptions in the reception of and reaction to the dominant discourse of silence. ${ }^{42}$ The case of the Lesvos exhumations reveals a negotiated and localized counter-discourse to State silence similar to that of Spain. There too, the hegemonic silence was received and recycled into a different representation of the past, through the re-burial of the left-wing victims.

\section{Local Memories within and beyond National Silence}

During the dictatorship and to a large extent the transition period, the memories of the left were, both in Spain and in Greece, 'underground memories.43 They were forced into public silence, but the events were not forgotten by civil society. As Michael Pollak puts it, when the past remains silent, it is often the work of memory according to its possibilities of communication. ${ }^{44}$ Silence does not mean that memory is not working behind the scenes. Silence can be the form in which memory actually expresses itself in the public sphere, because other forms are impossible at that moment. What is more, Jay Winter has argued that silence must be examined as part of the cartography of recollection and remembrance. ${ }^{45}$ As exhumations in that period show, we should not only focus on the institutional silence on the past during the Spanish and Greek transitions, but also on memory working at a local level, in the form adapted to the apparent realm of possibility.

There are striking similarities between the exhumations carried out in Spain and in Greece. However, they do not seem to be directly connected. In both cases, they were local initiatives coming from below, emerging independently from one another. This points to a transnational reception of the discourses promoting and implementing silence about the violent past from above. In this sense, we are not referring to the movement and interaction of memory discourses across space, ${ }^{46}$ but more to a common cultural and political

\footnotetext{
$42 \quad$ Ibid., 176.

43 Michael Pollak, Memoria, Olvido, Silencio. La Producción Social de Identidades Frente a Situaciones Límite. (La Plata: Ediciones Al Margen, 2006).

44 Ibid., 31.

45 Jay Winter, "Thinking about Silence," in Shadows of War. A Social History of Silence in the Twentieth Century, ed. Efrat Ben-Ze'ev, Ruth Ginio, and Jay Winter (Cambridge: Cambridge University Press, 2010), 3, http://dx.doi.org/10.1017/CBO9780511676178.002.

46 Astrid Erll, “Travelling Memory," Parallax 17, no. 4 (2011): 4-18, doi:10.1080/13534645.2011.6 05570.
} 
ground - or intellectual and cultural tradition in Kansteiner's scheme ${ }^{47}$ - on which similar and simultaneous forms of counter-discourses to a dominant discourse are constructed.

Rituals of death and burials are culturally and historically bound, but they can also get to represent a discourse that transcends those cultural borders. The exhumations responded to a moral imperative - dignifying the dead - that is larger than the national and local cultural contexts. Although practices of dignification take different forms and cannot be generalized, the fact that local counter-discourses to State silence about violent pasts took similar forms in different places at the same time points to the greater transcendence of memory and resistance to silence. The local memory practices are entangled within a larger set of transnational practices of mourning and of memory embedded within a larger discourse based on the moral obligation to respect and honor the dead. But these practices also blend with transnational political discourses of memory and justice. As a result, the local memory discourse bypasses the national discourse of silence about the past to reach another level. In more recent periods, the human rights paradigm has been a crucial framework to develop a transnational memory discourse of truth, justice and reparation, in which the practices and terminology have become transnationally connected. ${ }^{48}$ Nevertheless, even without a clear connection and interaction, transnational discourses of the dignification of victims were at play before the globalized discourse on human rights.

Suggesting another point of view and shedding new light upon the memory practices that were hitherto not considered transgressive or dissident shows that the transitional silences on the past have actually been responded to. The reactions to the dominant discourse are not always spectacular, and sometimes they need to be made visible and recognized as part of the politics of memory, with their contradictions or particularities. ${ }^{49}$ Making those silenced voices audible also shows that they have an important role in the struggle of memory discourses, in this case revealing the transcendence of the desire to dignify one's victims.

47 Kansteiner, "Finding Meaning in Memory: A Methodological Critique of Collective Memory Studies," 180.

48 Francisco Ferrándiz, "Exhuming the Defeated: Civil War Mass Graves in 21st-Centry Spain," American Ethnologist 40, no. 1 (2013): 38-54, doi:10.1111/amet.12004.

Zoé de Kerangat, "(In)visibilidad Y Lucha Familiar: Mujeres Y Memorias de La Represión En Las Décadas de Los 70 Y 8o," in Pasados de Violencia Política. Memoria, Discurso Y Puesta En Escena, by Memorias en Red, ed. Jean-François Macé and Mario Martínez Zauner (Madrid: Anexo, 2016), 177 . 


\section{Acknowledgements}

This publication was possible thanks to the project $\mathrm{CSO}_{2015}$-66104- $\mathrm{R}$ "The underground past: exhumations and memory politics in contemporary Spain in transnational and comparative perspective" funded by the Spanish Ministry of Economy and Competitiveness, and to the project "UNREST Unsettling Remembering and Social Cohesion in Transnational Europe", funded by the European Commission program H2020-REFLECTIVE-SOCIETY-2015. I am also very thankful to both Aline Sierp and Tea Sindbæk Andersen for their insightful comments on the first version of this paper.

\section{Bibliography}

Aguilar, Paloma. "Justice, Politics and Memory in the Spanish Transition." In The Politics of Memory. Transitional Justice in Democratizing Societies, edited by Alexandra Barahona de Brito, Carmen González Enríquez, and Paloma Aguilar, 92-118. Oxford: Oxford University Press, 2008.

Aguilar, Paloma. Políticas de La Memoria YMemorias de La Política : El Caso Español En Perspectiva Comparada. Madrid: Alianza, 2008.

Aguilar, Paloma, and Francisco Ferrándiz. "Memory, Media and Spectacle: Interviú's Portrayal of Civil War Exhumations in the Early Years of Spanish Democracy." Journalof Spanish CulturalStudies 17, no.1 (2016):1-25. doi:10.1080/14636204.2015.1135599. Aguirre González, Jesús Vicente. Aquí Nunca Pasó Nada. La Rioja 1936. $5^{a}$ edición. Logroño: Editorial Ochoa, 2008.

Anonymous, Funeral a Los Fusilados de Arnedo. Arnedo, 1980.

Box, Zira. España Año Cero. La Construcción Simbólica Del Franquismo. Madrid: Alianza, 2010.

Campos Orduña, Josefina. Los Fusilados de Peralta, La Vuelta a Casa (1936-1978). Operación Retorno. Pamplona/Iruña: Pamiela, 2008.

Casanova, Julián. España Partida En Dos: Breve Historia de La Guerra Civil Española. Barcelona: Crítica, 2013.

Close, David. "The Road to Reconciliation? The Greek Civil War and the Politics of Memory in the 1980s." In The Greek Civil War. Essays on a Conflict of Exceptionalism and Silences, edited by Philip Carabott and Thanasis D. Sfikas, 257-278. Aldershot: Ashgate, 2004.

Cohen Salama, Mauricio. Tumbas Anónimas. Informe Sobre La Identificación de Restos de Víctimas de La Represión Ilegal. Buenos Aires: Catálogos editora, 1992.

Davis, Andrea. "Enforcing the Transition: The Demobilization of Collective Memory in Spain, 1979-1982." Bulletin of Hispanic Studies 92, no. 6 (2015): 667-689. doi:10.3828/ bhs.2015.40. 
De Kerangat, Zoé. “(In)visibilidad Y Lucha Familiar: Mujeres Y Memorias de La Represión En Las Décadas de Los 70 Y 8o." In Pasados de Violencia Política. Memoria, Discurso Y Puesta En Escena, by Memorias en Red, 155-179. edited by Jean-François Macé and Mario Martínez Zauner. Madrid: Anexo, 2016.

Dreyfus, Jean-Marc. "Une Renationalisation Des Corps? La Mission Française de Recherches Des Cadavres de Déportés En Allemagne, 1946-1958." In Cadavres Impensables, Cadavres Impensés, edited by Elisabeth Anstett, 67-78. Paris: Pétra, 2012.

Erll, Astrid. "Travelling Memory." Parallax 17, no. 4 (2011): 4-18. doi:10.1080/13534645.2 011.605570 .

Ferrándiz, Francisco. El Pasado Bajo Tierra: Exhumaciones Contemporáneas de La Guerra Civil. Barcelona: Anthropos, 2014.

Ferrándiz, Francisco. "Exhuming the Defeated: Civil War Mass Graves in 21st-Centry Spain." American Ethnologist 40, no. 1 (2013): 38-54. doi:10.1111/amet.12004.

Foucault, Michel. "Truth and Power (interview with Alessandro Fontana and Pasquale Pasquino)." In The Foucault Reader, edited by Paul Rabinow, Pantheon., 51-75. New York, 1984 .

Joyce, Christopher, and Eric Stover. Witnesses from the Grave. From Mengele to Argentina's "Disappeared" - The Stories Bones Tell. London: Grafton, 1993.

Kansteiner, Wulf. "Finding Meaning in Memory: A Methodological Critique of Collective Memory Studies." History and Theory 41 (2002): 179-197.

Mbembe, Achille. "Necropolitics." Public Culture 15, no. 1 (2003): 11-40.

Ministerio de Hacienda, "Real Decreto 2635/1979, de 16 de Noviembre, Para La Aplicación Y Cumplimiento de La Ley 5/1979, de 18 de Septiembre, Sobre Concesión de Derechos a Los Familiares de Los Españoles Fallecidos Como Consecuencia O Con Ocasión de La Pasada Guerra Civil," 16 November 1979. Agencia Estatal Boletín del Estado. https://www.boe.es/diario_boe/txt.php?id=BOE-A-1979-27535.

Pollak, Michael. Memoria, Olvido, Silencio. La Producción Social de Identidades Frente a Situaciones Límite. La Plata: Ediciones Al Margen, 2006.

Prieto, Joaquín. "La Bandera Nacional Ondeará En Los Actos Del Partido Comunista de España." El País, 16 April 1977. http://elpais.com/diario/1977/o4/16/ espana/229989610_850215.html.

Scott, James. Domination and the Arts of Resistance: Hidden Transcripts. New Haven and London: Yale University Press, 1990.

Sharpe, Jim. "Historia Desde Abajo." In Formas de Hacer Historia, edited by Peter Burke, Segunda edición., 39-58. Madrid: Alianza, 2003.

Silva, Emilio. Las Fosas de Franco. Madrid: Temas de Hoy, 2005.

Stefatos, Katerina, and Iosif Kovras. "Buried Silences of the Greek Civil War." In Down to Earth: Exhumations in the Contemporary World, edited by Francisco Ferrándiz and Antonius Robben, 159-183. Philadelphia: University of Pennsylvania Press, 2015. 
Verdery, Katherine. The Political Lives of Dead Bodies. New York: Columbia University Press, 1999.

Winter, Jay. Sites of Memory, Sites of Mourning. The Great War in European Cultural History. Cambridge: Cambridge University Press, 1995.

Winter, Jay. "Thinking about Silence." In Shadows of War. A Social History of Silence in the Twentieth Century, edited by Efrat Ben-Ze'ev, Ruth Ginio, and Jay Winter, 3-31. Cambridge: Cambridge University Press, 2010. http://dx.doi.org/10.1017/ CBO9780511676178.002. 